\title{
PENINGKATAN MINAT BELAJAR BAHASA INGGRIS BAGI SISWA MTS. RAUDLATUL ULUM KECAMATAN PANTI KABUPATEN JEMBER MELALUI PENGEMBANGAN MEDIA PEMBELAJARAN VIDEO CONVERSATION 1)
}

\author{
Yuslaili Ningsih, S.Pd, M.Pd 2), Hariyono Rakhmad, S.Pd, M.Kom³)
}

1) Dibiayai dana DIPA Politeknik Negeri Jember

2) Jurusan Bahasa Komunikasi dan Pariwisata,

3) Jurusan Teknologi Informasi Politeknik Negeri Jember

\begin{abstract}
ABSTRAK
Madrasah Tsanawiyah Raudlatul Ulum ini berada di Desa Suci, Kecamatan Panti ini merupakan lembaga pendidikan tingkat menengah pertama di bawah Yayasan Pendidikan Islam Raudlatul Ulum. MTs ini baru berdiri sekitar 2 tahun yang lalu sehingga pada tahun 2015 ini baru terdiri dari dua kelas paralel, yaitu kelas VII dan VIII saja. Dalam melaksanakan aktivitas kegiatan proses belajar mengajar, mengingat sekolah ini masih tergolong masih baru, maka sarana dan prasarana pembelajaran juga masih minim. Satu hal harapan dari pimpinan sekolah ini adalah bahwa sekolah ini menekankan prestasi pada bidang bahasa, baik bahasa Arab maupun bahasa Inggris. Namun, dalam pembekalan pendidikan bahasa masih terkendali dengan belum adanya laboratorium bahasa dan media pembelajaran, termasuk alat berupa multimedia projector.

Tujuan dari kegiatan Pengabdian kepada Masyarakat ini adalah memberikan sarana pendukung untuk media pembelajaran bahasa seperti alat audio video dan projector yang terjangkau dalam pelajaran bahasa Inggris, sehingga wawasan bahasa siswa menjadi lebih luas. Beberapa tahapan dalam pelaksanaan kegiatan Pengabdian kepada Masyarakat ini adalah diawali dengan: (1) Studi pustaka; (2) Survei lapangan; (3) Desain dan pembuatan media pembelajaran; (4) Penyerahan alat dan pengarahan;

(5) Memantau perkembangan (6) Evaluasi dan pelaporan.
\end{abstract}

Kata kunci: Multimedia Interaktif, Pembelajaran Bahasa Inggris

\section{PENDAHULUAN}

Madrasah Tsanawiyah Raudlatul Ulum berada di Desa Suci, Kecamatan Panti ini merupakan lembaga pendidikan tingkat menengah pertama di bawah Yayasan Pendidikan Islam Raudlatul Ulum. MTs ini baru berdiri sekitar 2 tahun yang lalu sehingga pada tahun 2015 ini baru terdiri dari dua kelas paralel, yaitu kelas VII dan VIII saja.

Dalam melaksanakan aktivitas kegiatan proses belajar mengajar, mengingat sekolah ini masih tergolong masih muda, maka sarana dan prasarana pembelajaran juga masih minim. Satu hal harapan dari pimpinan sekolah ini adalah bahwa sekolah ini menekankan prestasi pada bidang bahasa, baik bahasa Arab maupun bahasa Inggris. Namun, dalam pembekalan pendidikan bahasa masih terkendala dengan belum adanya laboratorium bahasa ataupun media pembelajaran yang cukup memadai, sehingga minat siswa yang belajar di sini utamanya pada materi bahasa Inggris dinilai cukup kurang.

Siswa-siswi di madrasah ini mayoritas adalah para santri yang 
sedang ikut pondok pesantren. Bahasa yang menjadi target pembelajaran selain bahasa Arab juga bahasa Inggris, sehingga pelajaran bahasa Inggris juga harus dikuasai di samping bahasa Arab.

Proses belajar mengajar bahasa Inggris masih mengandalkan buku paket dan buku sumber bahasa Inggris. Sedangkan metode pengajarannya masih secara manual atau ceramah. Hal ini menyebabkan siswa mudah merasa bosan sementara media penunjang pembelajaran bahasa belum ada. Sehingga situasi pembelajaran seperti ini kurang efektif.

Padahal untuk mempelajari suatu bahasa diperlukan atmosfir budaya bahasa target sebagai wahana dalam proses pembelajaran. Hal ini dapat diwujudkan apabila pengajar atau guru mampu membawa atmosfir budaya tersebut ke dalam kelas. Sebagai contoh, guru mampu memberikan contoh percakapan bahasa Inggris terhadap siswa, namun sekali lagi hal ini terkendala dengan ketidaktersedianya media pembelajaran yang diperlukan, sehingga contoh-contoh percakapan tersebut tidak bisa dihadirkan ke dalam kelas.

Pertanyaannya adalah dapatkah tujuan pembelajaran bahasa di pondok pesantren ini tercapai dengan hanya menggunakan metode pembelajaran conventional. Berangkat dari pertanyaan inilah yang menjadikan tujuan utama adanya pengabdian kepada masyarakat ini dilaksanakan.

Untuk itu tujuan kegiatan pengabdian masyarakat ini adalah memberikan solusi kepada Madrasah Tsanawiyah Raudlatul Ulum di Dusun Gaplek, Desa Suci, Kecamatan Panti, Kabupaten Jember ini dengan pembuatan media pembelajaran Bahasa Inggris berupa video Conversation dengan multiproyektor sebagai media penunjang operasionalnya yang diharapkan dapat meningkatkan minat belajar siswa MTs. Raudlatul Ulum ini.
Dari analisis situasi, dapat diuraikan permasalahan mitra program Pengabdian Kepada Masyarakat ini yang muncul dan menjadi prioritas sebagai berikut:

1. Kurangnya minat belajar para siswa madrasah dalam pelajaran bahasa Inggris karena tidak adanya media pembelajaran yang menarik.

2. Nilai pelajaran bahasa Inggris ratarata cukup, sehingga perlu adanya peningkatan pembelajaran agar dapat meningkatkan nilai pelajaran dengan lebih baik.

3. Sarana pendukung untuk media pembelajaran bahasa seperti audio video dan projector belum ada.

4. Kurangnya buku pendukung dalam pelajaran bahasa Inggris, sehingga wawasan bahasa siswa menjadi kurang.

5. Siswa-siswi di madrasah ini paling banyak adalah para santri yang sedang ikut pondok pesantren, sehingga pelajaran bahasa Inggris menjadi target harus dikuasai di samping bahasa Arab.

6. Para tenaga didik khususnya yang mengampu pelajaran bahasa Inggris belum pernah menggunakan media pembelajaran baik dalam bentuk media interaktif maupun Video Conversation.

\section{TARGET DAN LUARAN}

\subsection{Target}

Target dari kegiatan Program Pengabdian Kepada Masyarakat untuk ini adalah:

1. Meningkatkan minat belajar para siswa madrasah dalam pelajaran bahasa Inggris dengan pembuatan media pembelajaran bahasa Inggris yang menarik sesuai dengan kurikulum yang berlaku.

2. Dengan meningkatnya minat, diharapkan meningkatkan pula nilai pelajaran bahasa Inggris dengan lebih baik.

3. Memberikan sarana pendukung untuk media pembelajaran bahasa 
seperti alat audio video dan projector yang terjangkau.

4. Pembuatan buku pendukung dalam pelajaran bahasa Inggris, sehingga wawasan bahasa siswa menjadi lebih luas.

5. Membantu memenuhi target agar siswa-siswi di madrasah ini yang mayoritas adalah para santri pondok pesantren dapat menguasai bahasa Inggris di samping bahasa Arab.

6. Menumbuhkan kesadaran terhadap manfaat teknologi dari para tenaga didik khususnya yang mengampu pelajaran bahasa Inggris agar selalu memberikan penggunaan media pembelajaran baik dalam bentuk media interaktif maupun Video Conversation Audio Visual.

7. Meningkatkan mutu pendidikan dan pengajaran pada madrasah ini.

8. Memberikan pemahaman kepada pengelola maupun tenaga kerja/karyawan serta para santri akan pentingnya dan bermanfaatnya media pembelajaran dalam meningkatkan minat dan semangat dalam belajar bahasa Inggris.

\subsection{Luaran dan Spesifikasinya}

Luaran dari kegiatan Program

Pengabdian Kepada Masyarakat Madrasah Tsanawiyah Raudlatul Ulum, Desa Suci, Kecamatan Panti, Kabupaten Jember adalah:

1. Buku Petunjuk Operasional sebagai bahan pelatihan cara mengoperasikan Video Conversation dalam pelajaran bahasa Inggris.

2. Media Pembelajaran yang berupa multi proyektor sebagai alat operasional media pembelajaran dan berfungsi sebagai audio visual media.

3. Video Conversation, adalah sebuah media berbasis audio visual yang berisikan materi percakapan dalam bahasa Inggris yang tepat dan sangat sesuai dengan masyarakat Indonesia. Adapun media ini didesain dengan konten sebagai berikut:

a. Chapter 1. Introduction

b. Chapter 2. Greeting and Parting

c. Chapter 3. Remark

d. Chapter 4. Asking Personal Information

e. Chapter 5. Repeats Offers and Preforms

f. Chapter 6. Telling Time and Date

\section{METODE KEGIATAN}

$\begin{array}{ccc}\text { Dari } & \text { sekian } & \text { banyaknya } \\ \text { permasalahan } & \text { mitra } & \text { Program }\end{array}$ Pengabdian Kepada Masyarakat yang telah diuraikan sebelumnya, maka metode pendekatan yang ditawarkan untuk dicarikan solusinya adalah dengan kesepakatan bersama antara tim Pelaksana Program Pengabdian Kepada Masyarakat Politeknik Negeri Jember dengan mitra yaitu melalui 5 tahap kegiatan adalah tahap studi pustaka, survei lapangan, desain media, tahap penyerahan alat kepada mitra, memberikan pelatihan dan pengarahan di lapangan, serta tahap memantau perkembangan.

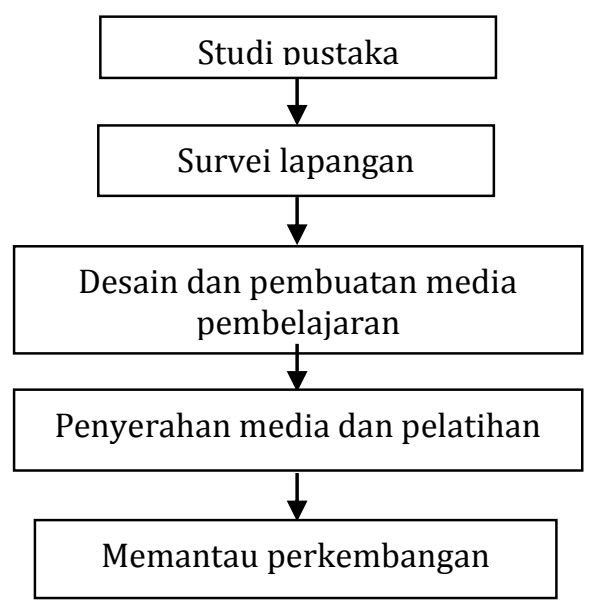

Gambar 1. Tahapan Kegiatan

1. Studi pustaka

Studi pustaka merupakan tahap paling awal yang digunakan, 
pencarian literatur untuk mencari bahan-bahan buku yang terkait yang sesuai dengan kurikulum yang berlaku dan akan diaplikasikan dalam kegiatan pengabdian ini.

2. Survei lapangan

Tahapan ini adalah mencari data dan informasi di lapangan yang diperlukan untuk pengerjaan aplikasi dari hasil tahap pertama. Tahap ini meliputi metode wawancara dan observasi.

3. Desain dan pembuatan media pembelajaran.

Tahap ini adalah pembuatan Video Conversation yang melibatkan mahasiswa program Studi Bahasa Inggris Politeknik Negeri Jember untuk melakukan acting percakapan untuk direkam dan dibuat Video Conversation.

4. Penyerahan alat dan pengarahan Adalah tahap penyerahan alat berupa media pembelajaran kepada mitra Pengabdian Kepada Masyarakat dan memberikan pengarahan cara menggunakannya termasuk dalam perawatan umum.

5. Memantau perkembangan

Tahap melihat perkembangan minat siswa dalam belajar bahasa Inggris dan memantau penggunaan media ini oleh para tenaga didik di Madrasah tersebut.

Pelaksanaan Program dan Peran Mitra, antara lain:

1. Tim pelaksana pengabdian melalui program Pengabdian Kepada Masyarakat ini adalah membuat buku atau petunjuk operasional media pembelajaran tersebut.

2. Tim pelaksana Pengabdian Kepada Masyarakat mendesain Video Conversation dengan melibatkan mahasiswa program studi Bahasa Inggris untuk melakukan praktik percakapan dalam bahasa Inggris.
3. Peran mitra secara aktif mengikuti dengan seksama pelatihan penggunaan media pembelajaran tersebut yang kemudian diserahterimakan oleh tim pelaksanaan program Pengabdian Kepada Masyarakat kepada mitra.

4. Kemudian peserta atau mitra pengabdian ini mengaplikasikan media tersebut di kelas pada saat pembelajaran bahasa Inggris tersebut.

5. Evaluasi dan pendampingan dilakukan setelah kegiatan pelatihan dilaksanakan. Peran mitra dalam pelaksanaan program ke depan adalah secara aktif dan terencana untuk dapat menggunakan media ini.

\section{HASIL DAN PEMBAHASAN}

Dalam kegiatan studi pustaka ini, tim mengumpulkan literature tentang media pembelajaran serta fungsi dan manfaatnya, pembuatan video, mengumpulkan materi yang disesuaikan dengan kebutuhan dan silabus pengajaran bahasa Inggris yang dipakai serta literatur pembuatan buku petunjuk operasional alat multi proyektor yang digunakan untuk memutar vcd conversation bahasa Inggris.

Dari hasil studi pustaka diperoleh informasi tentang media pembelajaran atau dalam bahasa inggrisnya teaching media adalah media yang digunakan untuk menyampaikan pesan kepada siswa yang dapat merangsang pemikiran, perasaan, perhatian dan keinginan sehingga tujuan pembelajaran dapat tercapai dengan baik. Media pembelajaran dibagi menjadi 2 yaitu tradisional dan modern.

Jenis media pembelajaran yang akan dibuat untuk program pengabdian masyarakat ini adalah media modern yaitu berupa video yang di dalamnya berisi contoh percakapan bahasa Inggris yang diperankan oleh non-native 
speaker sesuai dengan tema-tema materi yang diajarkan. Media pembelajaran modern itu merupakan penggunaan media pembelajaran dengan teknologi yang lebih tinggi termasuk di dalamnya teknologi digital seperti vcd, cd, e-book, komputer, dan lain-lain. Hal ini karena media pembelajaran modern lebih efektif dalam proses belajar mengajar.

Fungsi media pembelajaran menurut Sadiman (1990) antara lain; memperjelas penyampaian pesan atau dalam hal ini materi pelajaran, menghindari keterbatasan, waktu, tempat, dan rasa. Yang dimaksudkan di sini adalah media dapat berfungsi untuk menghadirkan situasi, tempat, dan pandangan yang berbeda atau berada jauh ke dalam kelas. Media juga berfungsi meningkatkan minat dan ketertarikan siswa dalam proses belajar, serta dapat memberikan pengalaman dan persepsi tentang materi yang disampaikan.

Manfaat media pembelajaran antara lain; dapat menstimuli otak dalam berbagai hal, memperbanyak pengalaman siswa, menghindarkan keterbatasan ruang, waktu, dan rasa, merupakan sarana interaksi antara siswa dan lingkungan, menimbulkan minat dan ketertarikan siswa, meningkatkan motivasi belajar siswa, wawasan, memberi kesempatan siswa belajar mandiri, meningkatkan kesadaran sosial, dan meningkatkan kemampuan siswa dan guru untuk mengekspresikan diri.

Materi yang termuat dalam produk luaran yang dihasilkan adalah:

a. Chapter 1. Introduction:

Scene 1: Self Introduction

Scene 2: Introducing others

b. Chapter 2. Greeting and Parting

Scene 1: Greeting

Scene 2: Parting

c. Chapter 3. Remark

Scene 1: Polite Remarks and Apologizes d. Chapter 4. Asking Personal Information

e. Scene 1: name, origin, job, address, phone number, age, nationality, marital status.

f. Chapter 5. Request, Offers and Preforms

Scene 1: Request, Offers and Preforms

g. Chapter 6. Telling Time and Date

Scene 1: Telling Time and Date

\section{Survey Lapangan}

Tahapan dalam survey ini meliputi wawancara dan observasi pada mitra. Dari hasil wawancara terhadap siswa, mereka menemui kesulitan dalam belajar bahasa Inggris dikarenakan kurangnya contoh atau model terutama untuk contoh percakapan dalam bahasa Inggris. Sumber belajar dari buku saja dan guru yang menerapkan sistem ceramah atau konvensional. Sehingga siswa merasa bosan dan kurang tertarik untuk belajar. Hal ini berakibat menurunnya minat dan motivasi belajar siswa. Terbukti dari nilai bahasa Inggris siswa yang kurang dari target capaian.

Sedangkan dari observasi lapangan diperoleh data bahwa, kesulitan dan kendala yang dihadapi mitra karena terbatasnya sarana dan prasarana belajar termasuk media belajar mengajar.

\section{Desain dan Pembuatan Media} Pembelajaran

Langkah pertama dalam pembuatan video ini adalah membuat konsep percakapan sesuai dengan script yang dibuat di setiap pokok bahasan. Kemudian script dibagikan kepada pemeran masing-masing karakter untuk dihafalkan. Tahap ini juga tahap mengatur laku pemain. Pemeran atau pemain dalam video ini adalah mahasiswa bahasa Inggris Jurusan Bahasa, Komunikasi, dan Pariwisata, Politeknik Negeri Jember. 
Setelah semua sudah siap, tahap kedua mulai dilakukan shooting video percakapan bahasa Inggris dengan setting area Politeknik Negeri Jember scene demi scene. Shooting ini beberapa kali diulang dan diedit karena faktor cuaca. Namun semuanya berjalan dengan lancar hingga proses mixing antara conversation dan ekspresi tiap pemain, serta finishing dan editing.

Tahap terakhir adalah finishing dan editing yang kemudian disimpan ke dalam bentuk vcd sebagai media pembelajaran percakapan bahasa Inggris yang berfungsi memberikan contoh-contoh percakapan bahasa Inggris. Tim Pengembang Multimedia efektif sebagai media pembelajaran dalam membantu guru menyampaikan materi sekaligus sebagai model yang mampu menarik perhatian siswa sehingga meningkatkan motivasi siswa dalam proses belajar bahasa Inggris.

a. Penyerahan alat dan pengarahan Penyerahan dilakukan oleh tim pelaksana pengabdian masyarakat kepada pihak Madrasah Tsanawiyah Raudlatul Ulum di Desa Suci, Kecamatan Panti, Kabupaten Jember khususnya kepada para guru sebagai user alat media pembelajaran. Alat ini berupa multiproyektor yang bisa digunakan untuk operasional vcd yang telah dibuat untuk mata pelajaran bahasa Inggris. Dalam hal ini diserahkan pula vcd conversation yang telah dibuat untuk diserahkan kepada mitra sebagai tambahan materi pelajaran bahasa Inggris khususnya speaking.

Tim pelaksana memberikan pengarahan secara detail tentang bagaimana alat tersebut digunakan untuk memutar vcd maupun digunakan untuk fungsi yang lainnya. Banyak hal yang ditanyakan oleh guru karena menurut mereka alat tersebut akan banyak membantu dalam proses belajar mengajar terutama dalam penyampaian materi yang lebih creatif dan inovatif. Para guru sangat antusias dalam mengikuti pengarahan cara operasional multiproyektor tersebut.

\section{b. Pelaksanaan Program}

Pelaksanaan program pengabdian masyarakat ini dilakukan pertama-tama adalah penyerahan alat multiproyektor dan bahan yaitu video conversation bahasa Inggris. Kemudian tim mulai melaksanakan:

1. Memberi pengarahan operasi alat multiproyektor kepada para guru agar mampu mengoperasikannya sewaktu digunakan sebagai media pengajaran terhadap siswa-siswi. Beberapa guru bertanya terutama tentang operasional alat tersebut di perbagai fungsi. Tanya jawab berlangsung seru terutama ibu-ibu guru yang merasa kurang paham dengan teknologi alat tersebut dan kurang berpengalaman dalam hal alat elektronik. Mereka sangat antusias mengikuti petunjuk langkah-langkah operasional mulai dari menghidupkan alat, memilih program, penyetelan, sampai mematikan alat tersebut. Hal ini sangat penting bagi mereka agar dapat mengoperasikan multiproyektor secara mandiri mengingat alat ini digunakan sebagai media pengajaran di depan murid-murid.

2. Memberi pelatihan singkat tentang cara mempergunakan alat tersebut.

3. Kemudian peran mitra adalah mengaplikasikan alat tersebut beserta video percakapan bahasa Inggris terhadap siswa-siswi dalam pelajaran bahasa Inggris.

\section{c. Evaluasi dan Pendampingan}

Evaluasi dan pendampingan pada saat pengaplikasian alat dilakukan tim pelaksana program pengabdian masyarakat terhadap peran mitra. Untuk selanjutnya, para guru baik ibuibu atau bapak-bapak guru tidak ada kesulitan dalam mengoperasikan alat tersebut. Proses belajar mengajar berjalan lancar. Para siswa terlihat 
sangat tertarik dan antusias saat media pembelajaran ini digunakan. Sehingga tercipta suasana belajar yang aktif dan meningkatkan motivasi belajar siswa. Interaksi antara guru dan murid sangat komunikatif dengan adanya media ini.

\section{KESIMPULAN}

Dari keseluruhan kegiatan pengabdian kepada masyarakat ini, dapat ditarik kesimpulan:

1. Meningkatnya minat dan motivasi belajar para siswa madrasah dalam pelajaran bahasa Inggris karena adanya media pembelajaran yang menarik.

2. Nilai pelajaran bahasa Inggris cukup meningkat, karena keefektifan media pembelajaran ini dalam proses belajar mengajar.

3. Sarana pendukung untuk media pembelajaran bahasa sudah terpenuhi dengan adanya multi projector dalam program pengabdian masyarakat ini.

4. Buku petunjuk penggunaan multiproyektor menjadi pedoman pengoperasian alat untuk kelancaran proses penggunaannya.

5. Pelajaran bahasa Inggris yang menjadi target luaran madrasah ini telah memenuhi tujuan yang ditargetkan untuk dikuasai di samping bahasa Arab.

6. Para tenaga didik khususnya yang mengampu pelajaran bahasa Inggris memiliki kepiawaian dalam menggunakan alat tersebut sebagai media pembelajaran baik dalam bentuk media interaktif maupun Video Conversation.

\section{DAFTAR PUSTAKA}

Alam, Agus J. 2005. Video Editing untuk Pemula dan Profesional dengan Pinnacle Studi Plus 9.3. Jakarta: Elex Media Komputindo.

Pannen, Paulina, dkk. 2005. Konstruktivisme dalam Pembelajaran. Jakarta: PAUPPAI, Universitas Terbuka

Pribadi, Benny Agus dan Dewi Padmo Pribadi. 2005. Ragam Media dalam Pembelajaran. Jakarta: PAU-PPAI, Universitas Terbuka

Sadiman. 1990. Strategi Pembelajaran. Jakarta Timur: Bumi Aksara

Sianipar, Pandapotan. 2005. Cara Mudah Menguasai Video Editing dengan Adobe Premiere Pro. Jakarta: Elex Media Komputindo.

Suparman, M. Atwi, dkk. 2005. Konsep Dasar Pengembangan Kurikulum. Jakarta: PAU-PPAI, Universitas Terbuka

Suyanto, M. 2003. Multimedia Alat untuk Meningkatkan Keunggulan Bersaing. Yogyakarta: Andi.

Vaughan, Tay. 2006. Multimedia: Making It Work. Edisi 6. Yogyakarta: Andi.

Wardani, IGAK. 2005. Dasar-dasar Komunikasi dan Keterampilan Dasar Mengajar. Jakarta: PAUPPAI, Universitas Terbuka

Winataputra, Udin S. 2005. Model-model Pembelajaran Inovatif. Jakarta: PAU-PPAI, Universitas Terbuka 